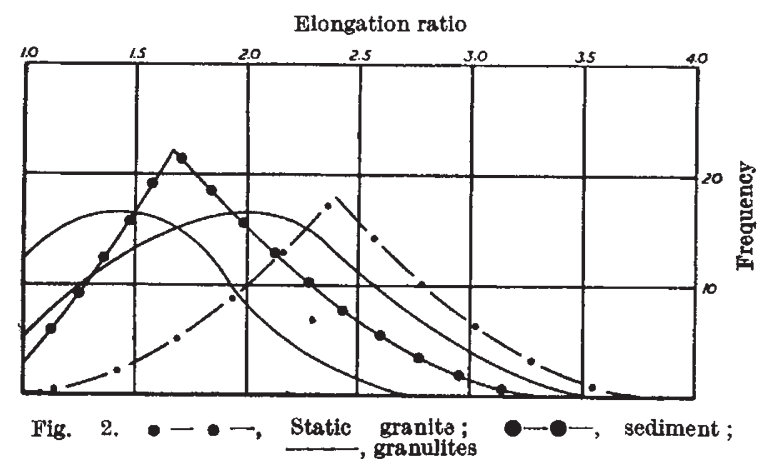

partly of sedimentary, partly of igneous material, contain both types of zircons. Hence elongationfrequency curves show two maxima, which may merge to one maximum at an elongation ratio of about $2 \cdot 0$. Other migmatites, having been formed metasomatically, show zircon elongation - frequency curves with only one maximum, at an elongation ratio less than $2 \cdot 0$. Recrystallization of zircon is nowhere evident.

In the second example (Fig. 2) static granite has been produced by ultra-metamorphism of sediments. The sedimentary zircons are again well rounded, and remain so throughout successive metamorphic grades, until the sillimanite grade is reached. At this stage zircons often exhibit granulation and, by such features as gradual disappearance of colour, peculiar outgrowths and fused aggregate crystals, show evidence of incipient recrystallization. Elongation - frequency curves have ill-defined maxima at progressively smaller elongation ratios. In yet higher metamorphic grades zircons become again larger and better formed, until finally they assume typical magmatic characters. Elongation - frequency curves now exhibit maxima at increasingly larger elongation ratios, finally exceeding $2 \cdot 0$.

Bechuanaland Protectorate Geological Survey, Lobatsi. Oct. 26.

${ }^{3}$ Geol. Soc. Amer., Mem., 28 (1948).

${ }^{2}$ Smithson, F., Geol. Mag., 76, 348 (1939).

'Dryden, A. L. Proc. U.S. Nat. Acad. Sci., 17, 233 (1931). - Poldervaart, A., and von Backström, J. W., Trans. Geol. Soc. S.
Africa. 32, 1 (1949).

\section{Non-Adaptive Characters}

IN reply to my letter asking Dr. Ford whether he had stated at last year's British Association meeting that, in his opinion, no character can ever have a neutral survival value, he stated that it was genes and not characters to which he referred. But he made two distinct statements. In the first, he stated that "genes . . . must very seldom [my italics] be of neutral survival value". This can only mean that sometimes a gene can have a neutral survival value. In the second statement, he says " . . . every one of these genes has a detectable influence on the viability of the organism", and this means that a gene can never have a neutral survival value. Will Dr. Ford tell us which of these statements is correct, for this was the very point on which certain competent geneticists asked unsuccessfully for further information at the Section D meeting? At the same time, will Dr. Ford explain what it is that he means by the adaptation of a gene ? The adaptation of a character is something which is easily understood by all biolo- gists; but the conception of adaptation of a gene is surely something that requires further explanation. The University, Manchester 13.

H. Graham Cannon

A RePLy to Prof. Graham Cannon's letter seems scarcely needed, for it is only necessary to read the statement in Nature, 164,882 (1949), to which it refers, not as detached half-sentences but as a whole, in order to ascertain the meaning of the two passages he cites. Prof. Cannon quotes, "genes . . . must very seldom be of neutral survival value". It looks as if he had not fully read my letter, since he adds, "This can only mean that sometimes a gene can have a neutral survival value". Had he passed to the next sentence, he would have seen the words : "That is by no means to say that they [the genes] are never so, ..." from which it could scarcely be in doubt that $\mathrm{I}$ do envisage the possibility that genes may occasionally be of effectively neutral survival value.

Prof. Cannon then goes on to quote a further detached half-sentence from my letter, " . . . every one of these genes has a detectable influence on the viability of the organism" with the comment, "and this means that a gene can never have a neutral survival value". In its context, it neither says nor means this. As reference to my letter will clearly show, I am here discussing the many known genes of Drosophila melanogaster. I do so to illustrate how rare (not non-existent, as I have already made clear) must be genes of neutral survival value, since every one of the hundreds so far studied influences viability, however trivial may be their visible effects. This, moreover, is exactly what I said at the British Association meeting. In reply, therefore, to Prof. Cannon's specific question, my two statements are in harmony and both are correct. It is important to notice that even though Prof. Cannon has not understood that my reference was to the known genes of Drosophila melanogaster, his own deduction from it is still quite illogical. Even if every one of the genes so far studied in the genetics of all organisms had a detectable effect on viability (which is not known to be true), this would not mean that a gene can never have a neutral survival value : it could not exclude the possibility of a rare situation which had not yet been encountered experimentally.

Finally, I have never once used the concept of the adaptation of a gene, which would presumably involve an adjustment in genic structure relative to the needs of the organism. Prof. Cannon has confused this with the idea that a gene may be of adaptive significance. A gene is not of significance in adaptation if it be disadvantageous or of neutral survival value; a gene may be of use in bringing about an adaptation if its effect is advantageous. The point to which Prof. Cannon presumably refers, though he does not say so, was the question "Can some of the trivial characters often used in taxonomy be regarded as non-adaptive ?" My answer was that they may be; but that the genes controlling them are not likely to be non-adaptive. That is to say, such genes will very seldom be of neutral value even when the char. acters in question are so. The adaptation of a gene was never even suggested, though the adaptation of the effects of a gene is a well-known phenomenon which has been studied experimentally.

\section{Department of}

$$
\text { E. B. Ford }
$$

Zoology and Comparative Anatomy,

University Museum, Oxford. 